\title{
PELAKSANAAN UPAYA KHUSUS (UPSUS) SWASEMBADA CABAI DAN BAWANG PUTIH
}

\author{
SPECIAL EFFORTS OF CHILLI AND GARLIC SUFFiCIENCY
}

\author{
${ }^{1)}$ Agus Dwi Nugroho, ${ }^{2)}$ Achmadi Priyatmojo, ${ }^{3}$ Sri Nuryani Hidayah U, ${ }^{4}$ Sujiyanto, ${ }^{5}$ Ika \\ Patmawati, ${ }^{6}$ Gandhi Vimala, ${ }^{7}$ Novian Rachmanda P, ${ }^{8}$ Raden Mas Abadi, ${ }^{9}$ Muhammad Fajar \\ Shodiq, ${ }^{10)}$ Muji Lestari, ${ }^{11)}$ Ibrahim Faisal Hutomo, ${ }^{12)}$ Afif Lathifah, ${ }^{13)}$ Ganang Gaga Prakoso \\ Fakultas Pertanian Universitas Gadjah Mada \\ Jl. Flora Bulaksumur Yogyakarta \\ email : agus.dwi.n@mail.ugm.ac.id
}

\begin{abstract}
ABSTRAK
Pemerintah melalui Kementerian Pertanian mengalokasikan Anggaran Pendapatan dan Belanja Negara Perubahan untuk mencapai pemenuhan kebutuhan cabai dan bawang putih dalam negeri. Salah satu strategi pengembangan usahatani cabai dan bawang putih adalah pemberdayaan petani. Tujuan kegiatan ini antara lain 1) melaksanakan penyuluhan dan pendampingan budidaya cabai-bawang putih dan pembuatan sarana produksi pertanian serta 2) melakukan pengawasan terhadap bantuan APBN-P cabai dan bawang putih. Kegiatan dilaksanakan di Desa Kentengsari Kecamatan Candiroto Kabupaten Temanggung. Kegiatan yang dilaksanakan antara lain penyuluhan dan pendampingan budidaya cabai dan bawang putih, pengawasan bantuan sarana produksi dan alat mesin pertanian tanaman cabai dan bawang putih serta penyuluhan dan pelatihan perbanyakan Bacillus sp. Hasil dari kegiatan pendampingan ini adalah mampu memberikan pengetahuan bagi petani tentang cara budidaya cabai dan bawang putih dengan baik serta petani memahami manfaat dan teknik perbanyakan Bacillus sp. Alokasi bantuan APBN-P dari pemerintah mengalami keterlambatan sampai ke petani yang mengakibatkan waktu penanaman mengalami kemunduran. Masalah dalam pelaksanaan UPSUS APBN-P yakni waktu pendampingan yang terlalu pendek dan bantuan sarana produksi sampai petani tidak tepat waktu. Pemerintah perlu memikirkan periode pendampingan yang efektif serta bantuan dapat diterima petani dengan tepat waktu.
\end{abstract}

Kata kunci : Cabai, Bawang Putih, Penyuluhan, Pendampingan, Pengawasan Bantuan

\section{ABSTRACT}

The government through the Ministry of Agriculture allocates the State Budget to achieve the fulfillment of domestic chili and garlic needs. Empowering farmers is one of the strategies for developing it. The aims of this community service are 1) conducting counseling and mentoring of chiligarlic cultivation and make agricultural production facilities and 2) supervising the assistance of the chili-garlic aid. The community service was held in Kentengsari Village, Candiroto Subdistrict, Temanggung Regency. The activities carried out included counseling and mentoring of chili and garlic cultivation, supervision of assistance for production facilities and farming machinery, and counseling \& training to increase Bacillus sp. The results of community service are able to provide knowledge for farmers about how to cultivate chili \& garlic and the benefits \& propagation techniques of Bacillus sp. The allocation of State Budget assistance has been delayed and made the planting time has been delayed. Another problem is the assistance time is too short. The government needs to think of effective assistance periods and the aid can receive on time.

Keywords: Chilli, Garlic, Counseling, Assistance, Supervision 


\section{PENDAHULUAN}

Konsumsi sayuran di Indonesia saat ini terus mengalami peningkatan. Pengeluaran makanan masyarakat Indonesia berupa sayuran dan buah mencapai $24 \%$ atau pengeluaran terbesar kedua setelah kelompok pangan roti dan sereal, terutama beras dan mie dari tepung gandum (White, et.al, 2009).

Pada kenyataannya, neraca perdagangan produk hortikultura Indonesia mengalami defisit karena jumlah impor lebih besar dari ekspor (Gambar 1). Beberapa komoditas hortikultura yang memiliki nilai impor cukup besar antara lain bawang merah, bawang putih dan cabai.

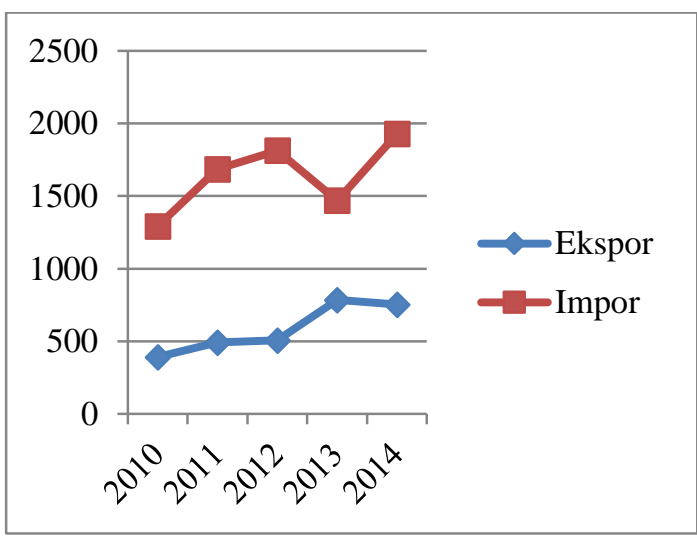

Gambar 1. Neraca Perdagangan

Hortikultura Indonesia Tahun 2010-2014 (dalam juta US\$)

Sumber : Pusdatin Kementerian Pertanian

Kondisi ini yang kemudian mendorong pemerintah melalui Kementerian Pertanian mengalokasikan Anggaran Pendapatan dan Belanja Negara Perubahan (APBN-P) untuk mencapai swasembada berkelanjutan dalam rangka pemenuhan kebutuhan dalam negeri dan peningkatan nilai ekspor. Salah satu kegiatan dalam APBN-P 2017 adalah peningkatan produksi tanaman hortikultura di Indonesia, terutama cabai dan bawang merah.

Kegiatan peningkatan produksi cabai dan bawang merah dapat dilakukan dengan partisipasi petani. Dalam hal ini, petani juga perlu kegiatan peningkatan kapasitas pengetahuan yang dapat dilakukan dengan menyelenggarakan pelatihan dan penyuluhan secara partisipatif, meningkatkan akses petani terhadap input, fasilitasi modal dan pasar serta meningkatkan koordinasi antara institusi pemerintah dan stakeholder (Aminah, 2015).

Berdasarkan keadaan tersebut, maka diperlukan peran serta Perguruan Tinggi untuk memberikan pendampingan dan pengetahuan bagi petani sehingga mampu meningkatkan produksi. Peran serta tersebut dilaksanakan dalam bentuk kegiatan pengabdian masyarakat. Tujuan dari pengabdian ini antara lain 1) melaksanakan penyuluhan dan pendampingan budidaya cabai-bawang putih dan pembuatan sarana produksi pertanian serta 2) melakukan pengawasan terhadap bantuan APBN-P cabai dan bawang putih.

\section{METODE}

Kegiatan pengabdian masyarakat ini merupakan bagian dari Upaya Khusus (UPSUS) swasembada pangan skema APBN-P. Sasaran dari kegiatan ini adalah kelompok tani pembudidaya cabai dan bawang merah di Desa Kentengsari dan merupakan penerima program APBN-P.

Pemerintah yang fokus pada peningkatan produksi pertanian dalam negeri kemudian membuat program untuk mengembangkan cabai dan bawang putih. Pemerintah melaksanakan berbagai kegiatan yang melibatkan Fakultas Pertanian Universitas Gadjah Mada. Kegiatan yang dilaksanakan antara lain : 
1. Penyuluhan dan pendampingan dilaksanakan mulai dari persiapan, tahapan pengolahan tanah, pemilihan varietas, penanaman benih/bibit dan pemeliharaan tanaman,

2. Pengawasan bantuan sarana produksi (saprodi) dan alat mesin pertanian (alsintan) tanaman cabai dan bawang putih, dan

3. Penyuluhan dan pelatihan perbanyakan Bacillus sp.

\section{HASIL DAN PEMBAHASAN}

\section{Penyuluhan dan Pendampingan Budidaya Cabai dan Bawang Putih}

Penyuluhan budidaya secara berkesinambungan merupakan aktivitas penting dalam rangka peningkatan efisiensi lahan (Sukiyono, 2005). Penyuluhan juga dalam rangka peningkatan dinamisasi kelompok tani sehingga mampu meningkatkann kesejahteraan petani (Perdana, 2016).

Kegiatan penyuluhan dan pendampingan di Desa Kentengsari dilaksanakan dengan melibatkan 3 (tiga) kelompok tani yakni Argo Lestari, Sido Mulyo dan Suka Karya. Ketiga kelompok tersebut merupakan penerima APBN-P 2017 komoditas cabai dan bawang putih.

Dalam kegiatan pendampingan, petani diberikan pengetahuan mengenai Good Agricultural Practices (GAP) budidaya cabai dan bawang putih (Gambar 2). SOP GAP budidaya cabai sebagai berikut (Sumarni \& Muharam, 2005) :

1. Benih dan varietas : cabai merah yang disarankan ditanam di dataran tinggi/medium yaitu Keriting, Hot beauty dan Lembang 1 . Untuk dataran rendah dapat dipilih varietas Keriting, Tit Super, Jatilaba, Prembun, Tanjung 1 dan Tanjung 2. Keperluan benih untuk 1 ha sekitar 300 - $400 \mathrm{~g}$,
2. Sistem tanam : pada lahan sawah bertekstur berat menggunakan sistem tanam 2-4 baris tanaman tiap bedengan. Pada lahan kering bertekstur sedang sampai ringan dengan sistem tanam 1 atau 2 baris tanaman tiap bedengan,

3. Pemulsaan : penggunaan mulsa jerami setebal $5 \mathrm{~cm} \quad\left(\begin{array}{ll}10 & \mathrm{t} / \mathrm{ha}\end{array}\right)$ atau menggunakan mulsa plastik bagor dan mulsa plastik hitam perak,

4. Penanaman : jarak tanam yang optimum berkisar antara $(50-60 \mathrm{~cm}) \times(40-50$ $\mathrm{cm}$ ), dan

5. Pemupukan : pupuk kandang $(15-20$ t/ha) dan pupuk SP - $36(300 \mathrm{~kg} / \mathrm{ha})$, yang dilakukan seminggu sebelum tanam. Pupuk kandang dihamparkan pada lubang tanaman, di atasnya diletakkan pupuk SP-36. Pupuk susulan terdiri atas pupuk Urea (200-300 kg/ha), ZA (300-400 kg/ha) dan KCl (250-300 $\mathrm{kg} / \mathrm{ha}$ ) yang diberikan 3 kali pada umur 3, 6 dan 9 minggu setelah tanam, masing-masing sepertiga dosis.

Sedangkan untuk SOP GAP budidaya bawang putih yakni

1. Benih dan varietas : benih bermutu dengan kebutuhan benih $600 \mathrm{~s} / \mathrm{d} 1.000$ $\mathrm{kg} / \mathrm{ha}$,

2. Penyiapan lahan : lahan disiram dengan Trichoderma sp dan ditambahkan dolomit, dibuat bedengan dengan lebar 1-1.5 $\mathrm{m}$ dan tinggi $20-25 \mathrm{~cm}$, ditambahkan pupuk kandang minimal 4 ton/ha,

3. Cara tanam : ditanam dengan sistem tugal yakni satu biji per lubang, jarak tanam $30 \mathrm{~cm} \times 30 \mathrm{~cm}$ (musim hujan) atau $30 \mathrm{~cm}$ x $20 \mathrm{~cm}$ (musim kemarau), penyulaman dilakukan pada saat tanaman berumur tidak lebih dari 7 hari dan pemupukan dengan pupuk organik dan anorganik sesuai anjuran, dan

4. Pengendalian hama/penyakit, hama utama bawang putih adalah ulat, jamur 
busuk umbi dan ujung pangkal. Pengendalian hama dapat dilakukan dengan pestisida hayati setiap seminggu sekali mulai hari kelima setelah tanam.

(Kementerian Pertanian, 2017):

Selain itu, pendampingan dilakukan dengan pengecekan benih cabai dan bawang putih. Kelompok tani yang mendapatkan bantuan APBN-P cabai pada kenyataannya menggunakan benih mandiri. Petani cabai yang tergabung dalam kelompok Suka Karya tidak mengalami kesulitan dalam penyediaan bibit. Sebagian besar petani Suka Karya menyediakan bibit cabai yang akan ditanam dengan menyemai sendiri. Sementara, beberapa petani lainnya dilakukan dengan membeli bibit yang siap tanam.

Berbeda dengan penyediaan bibit cabai, benih bawang putih di Desa Kentengsari merupakan benih hasil panen petani tahun sebelumnya atau petani membeli secara swadaya.

Sebagian besar petani yang tergabung dalam kelompok tani Sido Mulyo sudah memiliki benih bawang putih yang merupakan hasil panen tahun sebelumnya. Keadaan ini berbeda dengan kelompok tani Argo Lestari yang mengalami kesulitan dalam penyediaan benih bawang putih karena harga yang mahal. Hal tersebut terjadi karena penyedia benih bawang putih sudah mengetahui permintaan benih akan meningkat selaras pelaksanaan program APBN-P 2017 di Kabupaten Temanggung,

Anggota kelompok tani Argo Lestari memperoleh benih bawang putih dari Wonosobo dengan harga Rp 60 ribu per $\mathrm{kg}$ (sudak termasuk ongkos kirim sampai Temanggung). Benih bawang putih milik kelompok tani Sido Mulyo dan Argo Lestari dalam keadaan siap tanam yang dapat dilihat dari plumula benih.

Kegiatan pendampingan selanjutnya adalah penanaman cabai dan bawang putih di lahan (Gambar 3). Aktivitas ini dilaksanakan dengan pendampingan pengolahan lahan di kelompok tani Argo Lestari dan Sido Mulyo. Sampai dengan akhir November, anggota kelompok tani Argo Lestari yang menanam bawang putih ada dua orang. Begitu juga dengan kelompok Suka Karya penerima APBN-P cabai dimana sebagian besar petani sedang mengolah lahan. Anggota kelompok tani Suka Karya ada dua orang yang sudah menanam cabai.

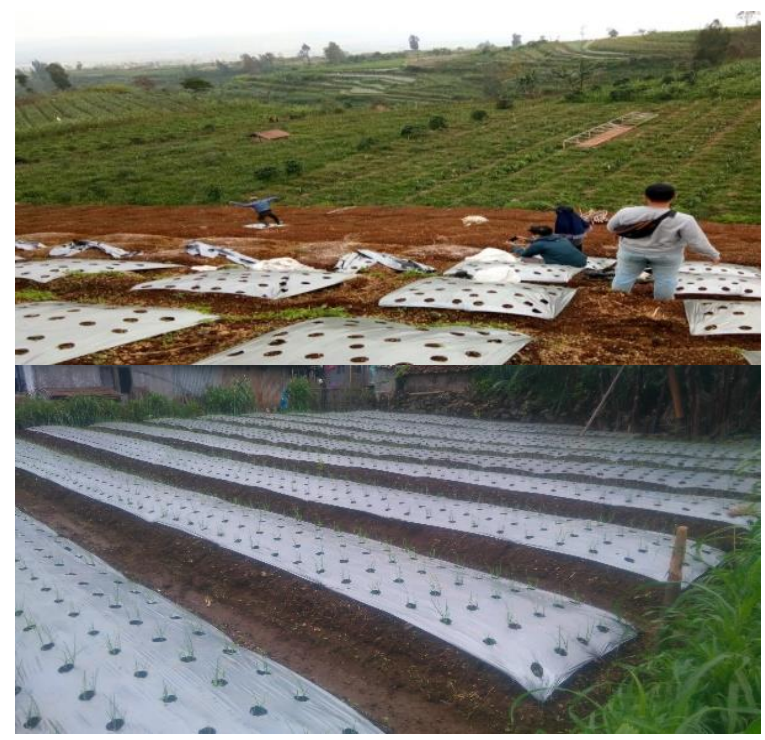

Gambar 3. Pendampingan Budidaya

Cabai dan Bawang Putih

\section{Pengawasan Bantuan Sarana Produksi (Saprodi) dan Alat Mesin Pertanian (Alsintan)}

Salah satu kegiatan dalam APBNP untuk pengembangan komoditas cabai dan bawang putih adalah bantuan sarana produksi yang meliputi pupuk organik, pupuk anorganik, sarana pengendali Organisme Pengganggu Tanaman (OPT) ramah lingkungan, mulsa dan/atau sarana lain yang diperlukan sesuai kondisi lokasi spesifik setempat. Langkah tersebut sangat tepat karena benih, pupuk, fungisida dan penggunaan mulsa akan meningkatkan produksi cabai merah (Istiyanti, dkk, 2015). 
Mekanisme pendistribusian bantuan adalah dari Dinas Pertanian dan Ketahanan Pangan Kabupaten Temanggung kemudian diteruskan ke Unit Pelaksana Teknis Dinas (UPTD) Kecamatan Candiroto dilanjutkan ke penyuluh lapangan dan kemudian disampaikan ke kelompok tani. Untuk Desa Kentengsari ada 3 kelompok tani yang menerima bantuan program APBN-P tanaman cabai dan bawang putih. Total lahan yang akan ditanami bawang putih di Desa Kentengsari adalah seluas 20 ha yang terbagi atas 2 kelompok tani. Sedangkan cabai hanya 1 kelompok dengan luas lahan yang ditanami cabai 5 ha (Tabel 1) dengan bantuan yang diterima tiap kelompok berbeda-beda disesuaikan dengan jenis komoditas dan jenis lahan (Tabel 2, 3 dan 4).

Tabel 1. Daftar Nama Kelompok Tani Penerima Bantuan APBN-P 2017 Desa Kentengsari Kecamatan Candiroto Kabupaten Temanggung

\begin{tabular}{cccc}
\hline No & $\begin{array}{c}\text { Nama } \\
\text { Kelompok }\end{array}$ & $\begin{array}{c}\text { Komodita } \\
\text { s }\end{array}$ & $\begin{array}{c}\text { Luas } \\
\text { Laha } \\
\text { na } \\
\text { (ha) }\end{array}$ \\
\hline 1 & Argo Lestari & $\begin{array}{c}\text { Bawang } \\
\text { putih }\end{array}$ & 10 \\
\hline 2 & Sido Mulyo & $\begin{array}{c}\text { Bawang } \\
\text { putih }\end{array}$ & 10 \\
\hline 3 & Suka Karya & Cabai & 5 \\
\hline
\end{tabular}

Sumber : Analisis Data Primer (2017)

Tabel 2. Daftar Bantuan yang Diterima Kelompok Tani Argo Lestari Desa Kentengsari Kecamatan Candiroto Kabupaten

Temanggung

\begin{tabular}{cll}
\hline No & Jenis Bantuan & Jumlah \\
\hline 1 & Mulsa & 100 roll \\
\hline
\end{tabular}

\begin{tabular}{clc}
\hline 2 & Dolomit & $13.200 \mathrm{~kg}$ \\
\hline 3 & Pupuk NPK & $7.500 \mathrm{~kg}$ \\
\hline 4 & Pupuk ZK & $1.500 \mathrm{~kg}$ \\
\hline 5 & POC & 200 liter \\
\hline 6 & Dekomposer & 100 liter \\
\hline 7 & BIO HYT & 120 liter \\
\hline 8 & Tricho zia & $130 \mathrm{~kg}$ \\
\hline 9 & Antracol & $20 \mathrm{~kg}$ \\
\hline 10 & Topsin & 20 liter \\
\hline 11 & Handsprayer & 10 unit \\
\hline 12 & Cultivator & 1 unit \\
\hline 13 & Pompa air & 1 unit \\
\hline
\end{tabular}

Sumber : Analisis Data Primer (2017)

Tabel 3. Daftar Bantuan yang Diterima Kelompok Tani Sido Mulyo Desa Kentengsari Kecamatan Candiroto Kabupaten Temanggung

\begin{tabular}{clc}
\hline No & Jenis Bantuan & Jumlah \\
\hline 1 & Mulsa & $100 \mathrm{roll}$ \\
\hline 2 & Dolomit & $13.200 \mathrm{~kg}$ \\
\hline 3 & Pupuk NPK & $7.500 \mathrm{~kg}$ \\
\hline 4 & Pupuk ZK & $1.500 \mathrm{~kg}$ \\
\hline 5 & POC & 200 liter \\
\hline 6 & Dekomposer & 100 liter \\
\hline 7 & BIO HYT & 120 liter \\
\hline 8 & Tricho zia & $130 \mathrm{~kg}$ \\
\hline 9 & Antracol & $20 \mathrm{~kg}$ \\
\hline 10 & Topsin & 20 liter \\
\hline 11 & Handsprayer & 10 unit \\
\hline 12 & Roda Tiga Viar & 1 buah \\
\hline
\end{tabular}

Sumber : Analisis Data Primer (2017)

Tabel 4. Daftar Bantuan yang Diterima Kelompok Tani Suka Karya Desa Kentengsari Kecamatan Candiroto Kabupaten Temanggung

\begin{tabular}{clc}
\hline No & Jenis Bantuan & Jumlah \\
\hline 1 & Mulsa & $100 \mathrm{roll}$ \\
\hline 2 & Dolomit & $4.360 \mathrm{~kg}$ \\
\hline 3 & Pupuk NPK & $7.500 \mathrm{~kg}$ \\
\hline 4 & Pupuk ZK & $1.000 \mathrm{~kg}$ \\
\hline 5 & POC & 700 liter \\
\hline 6 & Dekomposer & 100 liter \\
\hline 7 & Likat kuning & 160 buah \\
\hline 8 & BIO HYT & 130 liter \\
\hline 9 & Tricho zia & $100 \mathrm{~kg}$ \\
\hline
\end{tabular}




\begin{tabular}{clc}
\hline 10 & Antilla & $160 \mathrm{buah}$ \\
\hline 11 & Victory 80WP & $15 \mathrm{~kg}$ \\
\hline 12 & Raiden 200EC & 15 liter \\
\hline 13 & Alterna 90WP & $15 \mathrm{~kg}$ \\
\hline 14 & Cultivator & 1 unit/poktan \\
\hline 15 & Handsprayer & 10 unit \\
\hline 16 & Pompa air & 1 unit/poktan \\
\hline 17 & Roda Tiga Viar & 10 unit \\
\hline 18 & pH meter &
\end{tabular}

Seluruh bantuan sampai akhir November telah diterima kelompok tani namun distribusi saprodi dan alsintan tersebut terlambat sampai ke kelompok tani (Gambar 5). Contohnya adalah pendistribusian pupuk tanaman bawang putih belum diterima oleh kelompok tani padahal lahan sudah disiapkan dan siap tanam. Sebagian besar petani tidak dapat segera mengolah lahan dan memasang mulsa yang telah dibagikan karena menunggu bantuan pupuk. Pada akhirnya, petani anggota Kelompok Tani Suka Karya menggunakan pupuk swadaya terlebih dahulu. Sementara itu, hanya beberapa petani bawang putih di Kelompok Tani Argo Lestari dan Sido Mulyo yang mampu menyediakan pupuk secara swadaya.

Pupuk baru didistribusikan ke kelompok tani pada minggu terakhir bulan November sehingga menyebabkan petani mengalami keterlambatan pengolahan lahan. Penanaman bawang putih di Desa Kentengsari biasanya dilaksanakan pertengahan November. Keterlambatan penanaman sebenarnya dapat menyebabkan peningkatan risiko serangan Organisme Pengganggu Tanaman (OPT). Hal ini terjadi karena dampak perubahan iklim yang selanjutnya menyebabkan terjadinya penurunan produksi (Maulidah, 2012).

\section{Penyuluhan dan Pelatihan Perbanyakan Bacillus sp}

Salah satu teknologi ramah lingkungan adalah Bacillus sp yang merupakan bakteri yang memiliki fungsi melarutkan fosfat dan memfiksasi nitrogen sehingga tersedia untuk kebutuhan tanaman, meningkatkan pertumbuhan tanaman pada lingkungan kering dan menekan pertumbuhan mikroorganisme yang merugikan tanaman (Mukamto, dkk, 2015). Bacillus sp dapat meningkatkan kesuburan tanah dan memperbaiki kesehatan tanah sehingga memiliki dampak positif bagi pertumbuhan tanaman.

Masalah yang sering dikeluhkan petani adalah pengendalian OPT yang dapat menyebabkan gagal panen. Pada budidaya cabai, petani sering mengeluhkan serangan virus kuning. Serangan hama seperti ulat juga sering menyebabkan kekhawatiran di kalangan petani.

Beberapa petani juga mengalami kendala dalam penggunaan pestisida, insektisida, fungisida, herbisida yang melebihi rekomendasi penggunaan. Pengetahuan petani juga masih rendah terkait kandungan bahan aktif dalam produk tersebut. Petani memilih produk hanya berdasarkan rekomendasi dari petani lain tanpa mengetahui kandungan bahan aktif yang terkandung di dalamnya.

Beberapa petani juga sering mencampurkan beberapa produk sebelum mengaplikasikan ke tanaman. Petani kurang memahami bahwa praktik tersebut dapat menurunkan efektivitas produk dalam pengendalian OPT.

Kegiatan pelatihan pembuatan pupuk hayati, Bacillus sp, dilaksanakan di Desa Kentengsari dan dihadiri Petugas Penyuluh Lapangan Kecamatan Candiroto, Kepala Desa Kentengsari dan perwakilan dari kelompok tani di Desa Kentengsari.

Kegiatan pelatihan perbanyakan Bacillus sp bertujuan mendorong petani agar secara mandiri mampu memperbanyak Bacillus sp (Gambar 6). Materi dari penyuluhan ini membahas mengenai 
manfaat, cara aplikasi dan teknik perbanyakan Bacillus sp.

Secara umum petani tertarik untuk mengaplikasikan penggunaan Bacillus $s p$ pada lahan budidaya cabai dan bawang putih. Pada akhir kegiatan, petani diberikan sampel Bacillus sp dengan tujuan petani dapat melakukan perbanyakan secara mandiri dan mengurangi penggunaan pupuk kimia.

Hasil kegiatan ini mampu memberikan pengetahuan petani tentang manfaat dari Bacillus sp bagi pertumbuhan tanaman dan perbaikan lingkungan serta teknik untuk perbanyakan Bacillus $s p$.

Beberapa masalah yang dihadapi dalam pelaksanaan UPSUS APBN-P hampir sama dengan masalah yang dihadapi program UPSUS reguler (Nugroho, dkk, 2018) yakni periode pendampingan yang terlalu pendek sehingga tidak mampu sepenuhnya membantu pestani sampai dengan aktivitas panen dan bantuan sarana produksi yang sampai petani dengan tidak tepat waktu.

\section{SIMPULAN}

Kegiatan pendampingan mampu memberikan pengetahuan bagi petani tentang cara budidaya cabai dan bawang putih serta manfaat dan teknik perbanyakan Bacillus sp. Alokasi bantuan APBN-P dari pemerintah mengalami keterlambatan sampai ke petani yang mengakibatkan waktu penanaman mengalami kemunduran. Masalah dalam pelaksanaan UPSUS APBN-P yakni waktu pendampingan yang terlalu pendek dan bantuan sarana produksi sampai petani tidak tepat waktu. Pemerintah perlu memikirkan periode pendampingan yang efektif serta bantuan dapat diterima petani dengan tepat waktu.

\section{DAFTAR PUSTAKA}

Aminah, S. (2015). Pengembangan Kapasitas Petani Kecil Lahan Kering Untuk Mewujudkan Ketahanan Pangan. Jurnal Bina Praja, 7(3), 197 $-210$.

Istiyanti, E., Khasanah, U., \& Anjarwati, A. (2015). Pengembangan Usahatani Cabai Merah di Lahan Pasir Pantai Kecamatan Temon Kabupaten Kulon Progo. Agraris, 1(1), 6-11 .

Kementerian Pertanian, (2017). Pengembangan Cabai Nasional. Jakarta : Direktorat Jenderal Hortikultura Kementerian Pertanian

Maulidah, S., Santoso, H., Subagyo, H., \& Rifqiyyah, Q. (2012). Dampak Perubahan Iklim Terhadap Produksi dan Pendapatan Usahatani Cabai Rawit (Studi Kasus di Desa Bulupasar, Kecamatan Pagu, Kabupaten Kediri). SEPA, 8(2), 137-144.

Mukamto., Ulfah, S., Mahalina, W., Syauqi, A., Istiqfaroh, L., \& Trimulyono, G. (2015). Isolasi dan Karakterisasi Bacillus sp Pelarut Fosfat dari Rhizosfer Tanaman Leguminosae. Sains dan Matematika, 3(2), 62-68.

Nugroho, A. D., Fadillah, C. U., Astuti, R. P., Irmania, L. V., Lestari, C., Pinardi, S. T., Anjarwati, N., Bahtiar, E. W., \& Pratama, D. A. (2018). Pelaksanaan Program Upaya Khusus (UPSUS) Swasembada Pangan Berkelanjutan di Kabupaten Kendal Provinsi Jawa Tengah. Jurnal Pengabdian dan Pemberdayaan Masyarakat, 2(2), 287-296. 
Perdana, S. A. (2016). Pemberdayaan Kelompok Tani Melalui Pasar Lelang Sebagai Solusi Mewujudkan Kedinamisan Kesejahteraan Petani. Vigor: Jurnal Ilmu Pertanian Tropika dan Subtropika, 1(1), $52-63$.

Sukiyono, K. (2005). Faktor Penentu Tin gkat Efisiensi Teknik Usahatani Cabai Merah di Kecamatan Selupu Rejang, Kabupaten Rejang Lebong. Jurnal Agro Ekonomi, 23(2), 176-190.

Sumarni, N., \& Muharam, A. (2005). Budidaya Tanaman Cabai Merah. Bandung : Balai Penelitian Tanaman Sayuran.

White, B., Morey, P., Natawidajaja, R., \& Morgan, W. (2009). Rantai Nilai Sayuran di Kawasan Timur Indonesia Fokus pada Cabe. Canberra : ACIAR. 